\title{
Is US hurricane report being quashed?
}

A statement on the science behind the politically sensitive issue of hurricane activity and climate change has been blocked by officials at the US Department of Commerce, Nature has learned.

Work on the statement began this February after complaints about the actions of political appointees at the National Oceanic and Atmospheric Administration (NOAA), an agency that falls under commerce-department control. NOAA researchers accused the appointees of ignoring - on the agency's website and at press conferences - the possibility that global warming could cause hurricanes to become more intense or frequent. The agency was also accused of preventing scientists who believe there might be such a link from speaking out (see Nature 439, 896-897; 2006).

The link is a sensitive issue because of the devastation caused by Hurricane Katrina and the US government's reluctance to restrict the greenhouse-gas emissions that are driving climate change.

NOAA officials denied both of the accusations from researchers. But e-mails obtained under freedom-of-information legislation by the environmental group Greenpeace USA, based in Washington DC, show that several NOAA scientists told their seniors that the agency was not properly representing hurricane science. The scientists' complaints prompted the creation of an internal seven-member panel charged with preparing a consensus statement on the views of NOAA researchers on hurricane science. A draft seen by Nature states that global warming may be contributing to hurricane intensity and that further research is needed to clarify the issue.

The document was finalized by the panel in mid-May and was due to be released to the public and the media in time for the start of this year's hurricane season in June. But panel chair Ants Leetmaa, director of NOAA’s Geophysical Fluid Dynamics Laboratory at Princeton University, New Jersey, received an e-mail on 18 May from a commerce-department official informing him that the document needed to be made less technical and was not to be released. Leetmaa says department officials have not responded to his efforts to contact them since.

\section{Getting exercised}

When asked about the document, NOAA administrator Conrad Lautenbacher told Nature that it was simply an internal exercise designed to get researchers to respect each other's points of view. He said it could not be released because the agency cannot take an official position on a field of science that is changing so rapidly. But panel members contacted by Nature, including Leetmaa, disagree strongly with this interpretation. Internal NOAA and commerce-department e-mails also discuss the timetable for the document being "cleared" for "distribution". The draft states that it refers to the "current state of the science" and does not contain "any statements of policy or positions of NOAA".

NOAA's stance on hurricane science came in for further criticism last week. Details have

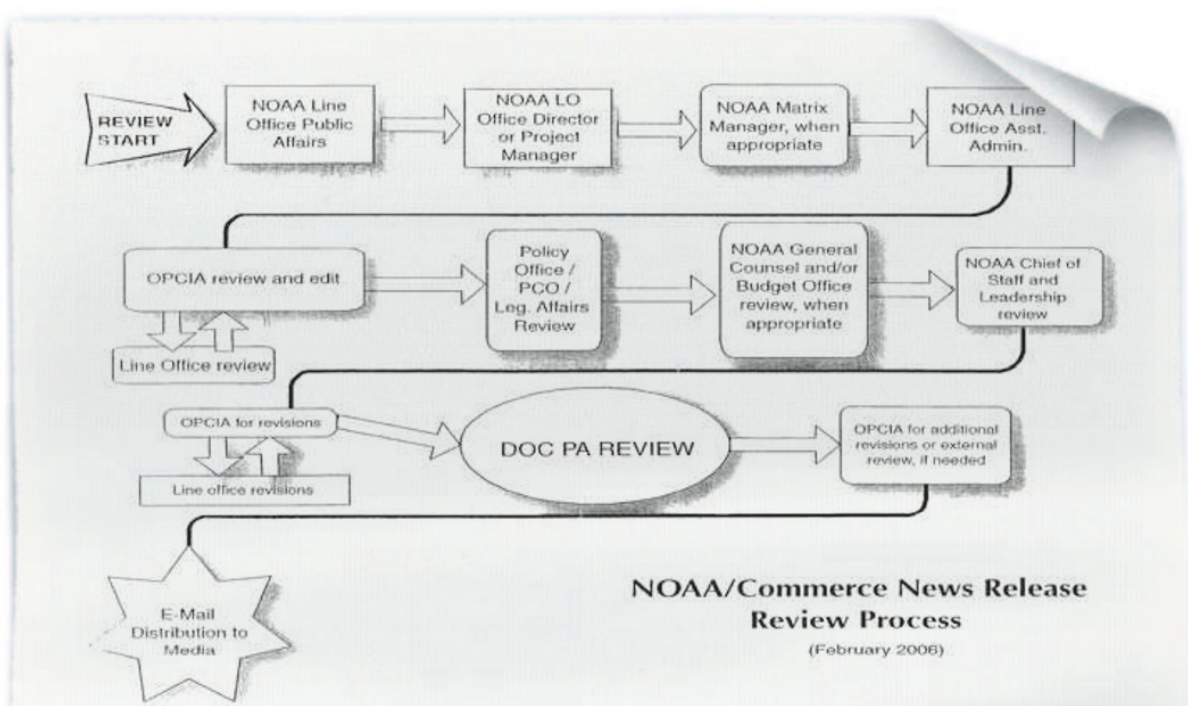

Paper trail: this flow chart for press releases was obtained under freedom-of-information legislation.

emerged of what critics interpret as government attempts to control media access to Tom Knutson, a NOAA researcher who has published papers suggesting that global warming may make Atlantic hurricanes more intense. E-mails obtained by the online news magazine Salon show that Chuck Fuqua, a press officer at the Department of Commerce, enquired about Knutson's views on global warming when considering an interview request from $\mathrm{CNBC}$ television. He then asked whether other NOAA researchers who dispute the warming link might be interviewed instead. One such researcher, Chris Landsea, is described in another e-mail as the "best source" to explain why climate change is not increasing hurricane activity.

Lautenbacher says the agency would not "condone anything that works in that way" and that he has taken steps to ensure that researchers are not prevented from talking to the press. Despite the blocked consensus report, it does now seem easier for scientists to speak to the media. A year or so ago, NOAA researchers complained of having to run interview requests by press officers, but scientists at the agency told Nature they are no longer required to do so. The documents obtained by Greenpeace do, however, indicate that NOAA press releases must still be seen by commerce-department officials as part of a 13-step approval process (pictured below). A department spokesperson says they need to see the releases so that they can prepare for enquiries, adding that officials would never change the scientific content of a release for non-scientific reasons.

Another of the complaints made earlier this year by NOAA researchers has also prompted an agency response, albeit a minor one. According to the Greenpeace e-mails, Knutson and colleagues complained about an article on NOAA's website, which claimed that the recent increase in Atlantic hurricane activity "is not related to greenhouse warming". The article, published last November, stated that there was a "consensus" in the NOAA that the intense 2005 hurricane season was due to natural variability. It was criticized by climate researchers, some of whom believe that global warming may have played a role in recent hurricane activity. The article itself remains unchanged, but the complaint did prompt the addition of a note at the end, stating that it does not represent the views of all NOAA researchers.

Jim Giles 